\title{
Public financial services transparency
}

\author{
Winston Logan
}

General Manager, Spitalfields Co. Ltd, London, England

\section{Oleksii Esmanov}

Ph.D., Head of the Department, State Auditor Service, Ukraine

\begin{abstract}
Reforming state financial control after Ukraine gained independence was characterized by significant changes, but they had a spontaneous and non-systemic character. Due to uncoordinated transformation, the financial control system still spends disproportionately large resources on its content, retains many features of the postSoviet period, especially in organizational and functional structures, the methods of work of control bodies, and therefore morally obsolete and practically does not provide necessary progress in stabilizing the financial and budgetary discipline in the state. As practice has shown, work organization of state financial control bodies requires significant resource costs (both labor and financial). The lack of coordination and systematization in activities of state financial control authorities does not allow optimizing the disposal and use of state financial resources, it stimulates the deepening of financial crisis in domestic economy.
\end{abstract}

Keywords: financial control, transparency, public authorities, financial crisis, national security.

JEL Classification: F52, G01.

DOI: $10.21272 /$ bel.1(2).62-67.2017.

(C) The Authors, 2017. This article is published with open access at ARMG Publishing.

\section{Introduction}

The main problems of our time are in the sphere of work organization of state financial control bodies, so we should pay as much attention to them as possible. Since Soviet times, these bodies directly responsible for public financial control are inherently closed, which reduces the opportunities for analyzing the effectiveness of their activities and corresponding effective reform. That is why, we strive to pay as much attention to the issues of transparency of state financial control and study the organizational features of its implementation with a view to scientifically substantiating the existence of a link between the openness of state financial control bodies and the level of financial discipline in society. Bringing the fact that the safety of state financial control can be considered as an integral indicator of work effectiveness of state financial control bodies, we will focus on its magnitude as an indicator of financial discipline and implementation of state financial control.

Institutions of state control are constantly subjected to organizational changes, which, of course, affects the effectiveness of their functioning. Thus, the need for an appropriate analytical apparatus, which would allow us to see clearly the effect of corresponding reorganization processes, is fully justified. In recent years, the demand for transparency in the management of state and public finances is not only a factor in strengthening democracy, but also as a means of solving economic problems. The functions of external and internal state control, at first glance, may seem to be mutually duplicative, but there are significant differences between them and the decision to merge the institutions of external and internal control of democracy.

\section{A brief analysis of recent measures to increase the transparency of state financial control}

Increasing openness for today is one of the key tasks in the process of reforming the state financial control system. On the one hand, this is the number of potential violations of legal discipline, based on a wide range of stakeholders. On the other hand, it raises the level of responsibility of officials of state financial control bodies for the diligent performance of their immediate responsibilities as a result of continuous monitoring of their activities. The following steps were taken to increase the effectiveness of public relations and provide information and legal assistance to citizens at the State Financial Inspection of Ukraine based on information provided in the reports of the State Financial Inspection of Ukraine for the period of 2010-2016:

a hotline operated; free access on the website of the State Financial Inspection of Ukraine to the sections 
"phone of trust" and "phone of confidence of the territorial bodies of the State Financial Inspection" was opened;

$>$ the State Financial Inspection of Ukraine actively cooperated with mass media and public in covering the results of control activities throughout the analyzed period. Information on results of activities of the State Financial Inspection of Ukraine is made public through domestic television and radio companies, news agencies, print and online publications.

$>$ In 2016, 3 briefings were held with the participation of administration of the State Financial Inspection of Ukraine. A briefing was held with the participation of the Chairman of the State Financial Inspection, where the results of activities of the State Financial Inspection of Ukraine were published in 2016.

$>$ During 2016 the governance of territorial bodies of the State Financial Inspection of Ukraine held 65 press conferences and briefings devoted to the prevention of corruption in the use of public fund.

$>$ Results of audits are regularly published in mass media, and in 2016 the divisions responsible for the publication of information on the directions of work and results of activities of the State Financial Inspection of Ukraine have prepared 21,202 information materials, and 286 were published on the official web portal of the Cabinet of Ministers of Ukraine. In addition, the citizens' access to information on the activities of the State Financial Inspection of Ukraine was provided by providing answers to requests from the media.

$>$ in 2016, in compliance with the requirements of the Law of Ukraine "On Access to Public Information", specialists of the State Financial Inspection of Ukraine provided responses to 108 information requests received from members of the public;

$>$ in 2016, the State Financial Inspection of Ukraine carried out 12 editions of Ukrainian scientific and practical journal Financial Control, which comprehensively highlights the results of state financial control, problematic issues and development plans of the State Financial Inspection of Ukraine.

All the foregoing gives us an opportunity to state that the issue of openness of bodies activities in the State Financial Inspection of Ukraine is not less important than other tasks performed by it, and its authority depends not only on professional performance of every employee in his official duties, but also to a large extent on the established public opinion on activities of the State of Financial Inspection of Ukraine.

\section{The influence of transparency on the status of financial security and state financial control (SFC)}

Considering all the above, we will analyze the impact of transparency of state financial control bodies on the state of financial security. With this purpose, we collected data on transparency indicators of the system of state financial control during 2010-2016.

The list of indicators characterizes the degree of openness of the State Financial Inspection of Ukraine and the Accounting Chamber of Ukraine for 2010-2016. It is shown in Table 1.

Table 1. Dynamics of transparency indicators of public financial control authorities during 2010-2016

\begin{tabular}{|c|c|c|c|c|c|c|c|}
\hline \multirow{2}{*}{ Indicators } & \multicolumn{7}{|c|}{ Years } \\
\hline & 2010 & 2011 & 2012 & 2013 & 2014 & 2015 & 2016 \\
\hline 1 & 2 & 3 & 4 & 5 & 6 & 7 & 8 \\
\hline $\begin{array}{l}\text { Number of press conferences and briefings } \\
\text { in the State Financial Inspection of Ukraine, } \\
\text { devoted to the prevention of corruption in } \\
\text { the use of public funds. }\end{array}$ & 10 & 10 & $\mathrm{n} / \mathrm{a}$ & 50 & 36 & 32 & 65 \\
\hline $\begin{array}{l}\text { Number of information materials on the } \\
\text { directions of work and results of activities } \\
\text { of the State Financial Inspection of } \\
\text { Ukraine, prepared by departments responsi- } \\
\text { ble for promulgating information in the } \\
\text { media. }\end{array}$ & 12000 & 16700 & $\mathrm{n} / \mathrm{a}$ & 19095 & 20087 & 17325 & 21202 \\
\hline $\begin{array}{l}\text { Number of answers of experts of the State } \\
\text { Financial Inspection of Ukraine to official } \\
\text { requests from media representatives. }\end{array}$ & $\mathrm{n} / \mathrm{a}$ & $\mathrm{n} / \mathrm{a}$ & $\mathrm{n} / \mathrm{a}$ & 45.00 & 46.00 & 42.00 & 49.00 \\
\hline $\begin{array}{l}\text { Number of responses of experts from the } \\
\text { State Financial Inspection of Ukraine to } \\
\text { information requests from members of the } \\
\text { public. }\end{array}$ & 3000 & 3600 & 4985 & 0 & 41 & 93 & 108 \\
\hline
\end{tabular}


Table 1 (cont.). Dynamics of transparency indicators of public financial control authorities during 2010-2016

\begin{tabular}{|c|c|c|c|c|c|c|c|}
\hline \multirow{2}{*}{ Indicators } & \multicolumn{7}{|c|}{ Years } \\
\hline & 2010 & 2011 & 2012 & 2013 & 2014 & 2015 & 2016 \\
\hline 1 & 2 & 3 & 4 & 5 & 6 & 7 & 8 \\
\hline $\begin{array}{l}\text { Number of information materials on the } \\
\text { directions of work and results of activities } \\
\text { of the Accounting Chamber of Ukraine, } \\
\text { published in the media. }\end{array}$ & 3822 & 7646 & 7594 & 13270 & 12175 & 8601 & 4961 \\
\hline $\begin{array}{l}\text { Number of information messages about } \\
\text { work of the State Financial Inspection of } \\
\text { Ukraine on the official website (in "News" } \\
\text { section). }\end{array}$ & 300 & 291 & н/д & 412 & 571 & 524 & 941 \\
\hline $\begin{array}{l}\text { Publication of the results of work of the } \\
\text { State Committee for Financial Monitoring } \\
\text { of Ukraine (in printed publications, through } \\
\text { television, broadcasting, etc.). }\end{array}$ & 14248 & 16647 & 18761 & 19532 & 20923 & 19424 & 25222 \\
\hline
\end{tabular}

Source: compiled from reports of the State Financial Inspection of Ukraine and the Accounting Chamber of Ukraine.

To calculate the transparency index, we will determine the correlation between transparency indicators and the level of security of state financial control and financial security (Stage 1, Figure 1).

Stage 1. Formation of an initial set of financial security indicators (137 indicators) and an information set for 2010-2016.

Stage 2. Formalization of correlation links of financial security indicators with GDP level and GDP growth rate.

Stage 3. Forming the final set of financial security indicators (only those whose correlation coefficient exceeds 0.75 ).

Stage 4. Normalization of financial security indicators by adjusting to values in the range $[0,1]$, taking into account the direction of influence on financial security.

Stage 5. Calculation of the level of financial security as the sum of the normalized values of all its indicators, taking into account their specific weight

$$
S_{F S}=\sum_{j=1}^{4} \sum_{k=1}^{n} p_{k j} \cdot h_{k},
$$

where $S_{F S}-$ the Level of financial security; $p_{k j}$ - the value of the $k$-th financial control indicator in the corresponding j-th group is normalized, which are divided by the nature of the impact; $h_{k}$-specific weight of the $k$-th financial security indicator.

Figure 1. Scientific and methodological approach to the definition of financial security

Source: compiled by authors.

Using this scientific and methodological approach, we move on to Stage 2 and Stage 3, obtaining necessary data to build a model for correlation between transparency and the level of security of state control and / or financial security. This analysis was the basis for calculating the transparency index of state financial control, calculated as the average for the year studied and the value of normalized indicators of state financial control openness and transparency. The required results of calculations are given in Table 2 (see in Appendix).

The final stage (Stage 4) of our study is the analysis of correlation between the transparency index and the level of security of state financial control and financial security.

Proposed scientific and methodological approach creates the possibility of determining the level of financial security with a high degree of reliability and has a number of advantages over the existing ones. This approach differs from existing ones in the following:

1. for a clear alignment of financial security assessment mechanism with the aim of ensuring it, the indicators of financial security include only those indicators whose correlation with macroeconomic characteristics of 
the country's socio-economic development and economic growth is dense, which made it possible to ensure a clear correspondence between the mechanism for calculating the goal of financial safety;

2. to consider not only current but also potential threats to financial security, the indicators are divided into two groups: direct action (a high correlation level with the GDP level) and a promising action (high correlation level with the rate of GDP growth);

3. to avoid duplication in calculations, there is no clear fixation of indicators behind the structural components of financial security.

As a result of calculations, we obtain a formalized level of financial security for the analyzed period from 2011 to 2016 (see Figure 2).

The level of financial security

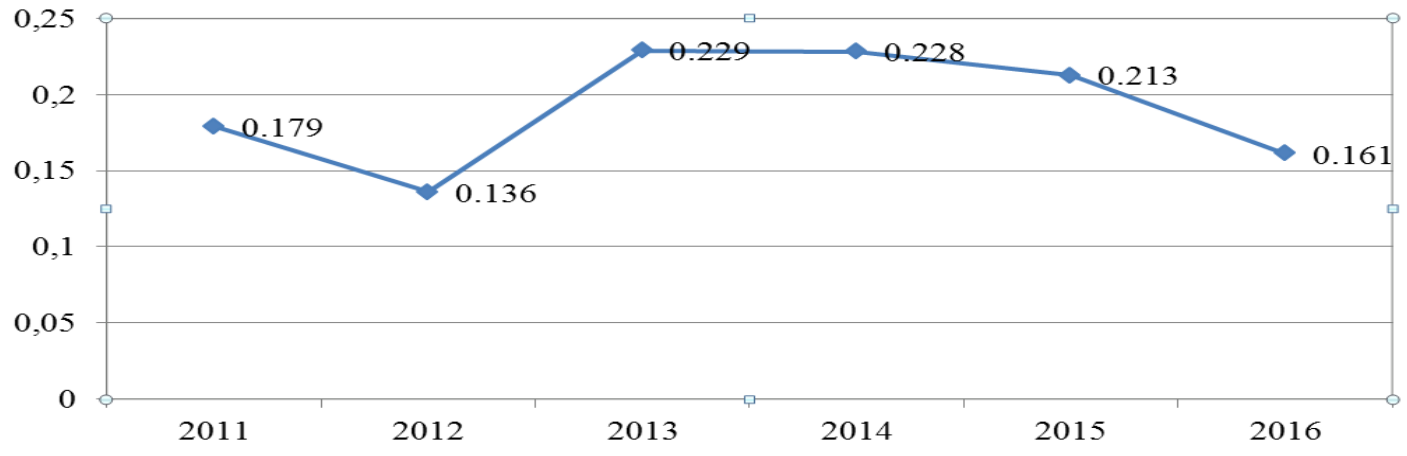

Figure 2. The dynamics of the level of financial security

Source: own calculations during 2011-2016.

To calculate the transparency index, we will define the average value of the above indicators during years under investigation and determine the correlation coefficients between the transparency indicators and the level of security of state financial control and financial security. The results are given in Table 3.

Table 3. Analysis of the relationship between the transparency indicators and the level of security of the state financial control and financial security

\begin{tabular}{|l|c|c|c|}
\hline \multicolumn{1}{|c|}{ Indicators } & $\begin{array}{c}\text { Correlation with the level } \\
\text { of security of state } \\
\text { financial control }\end{array}$ & $\begin{array}{c}\text { Correlation to the } \\
\text { level of financial } \\
\text { security }\end{array}$ & $\begin{array}{c}\text { Average value of } \\
\text { indicator for } \\
2007-2013\end{array}$ \\
\hline $\begin{array}{l}\text { Number of press conferences and briefings in the } \\
\text { State Financial Inspection of Ukraine, devoted to the } \\
\text { prevention of corruption in the use of public funds. }\end{array}$ & -0.11 & -0.10 & 33.8 \\
\hline $\begin{array}{l}\text { Number of information materials on the directions of } \\
\text { work and results of activities of the State Financial } \\
\text { Inspection of Ukraine, prepared by the departments } \\
\text { responsible for promulgating information in the } \\
\text { media. }\end{array}$ & 0.18 & -0.34 & 17264.4 \\
\hline $\begin{array}{l}\text { Number of answers of experts of the State Financial } \\
\text { Inspection of Ukraine to official requests from media } \\
\text { representatives. }\end{array}$ & 0.97 & -0.65 & 45.5 \\
\hline $\begin{array}{l}\text { Number of responses of experts from the State Finan- } \\
\text { cial Inspection of Ukraine to information requests } \\
\text { from members of the public. }\end{array}$ & 0.38 & -0.74 & 1689.6 \\
\hline $\begin{array}{l}\text { Number of information materials on the directions of } \\
\text { work and results of activities of the Accounting } \\
\text { Chamber of Ukraine, published in media. }\end{array}$ & -0.58 & 0.81 & 8295.6 \\
\hline $\begin{array}{l}\text { Number of information messages about work of the } \\
\text { State Financial Inspection of Ukraine on the official } \\
\text { website (in "News" section). }\end{array}$ & 0.17 & -0.45 & 19251 \\
\hline $\begin{array}{l}\text { Publication of results of work of the State Committee for } \\
\text { Financial Monitoring of Ukraine (in printed publica- } \\
\text { tions, through television, broadcasting, etc.). }\end{array}$ & 0.13 & & \\
\hline
\end{tabular}

Source: own calculations. 
Based on the results of the calculations, the correlation between the transparency index and the state of financial security is set at 0.62 , which is characterized by a significant density and forms the basis for the possibility of interpreting such a link by means of a linear regression expression. The relationship between these indicators is clearly shown in Figure 3.

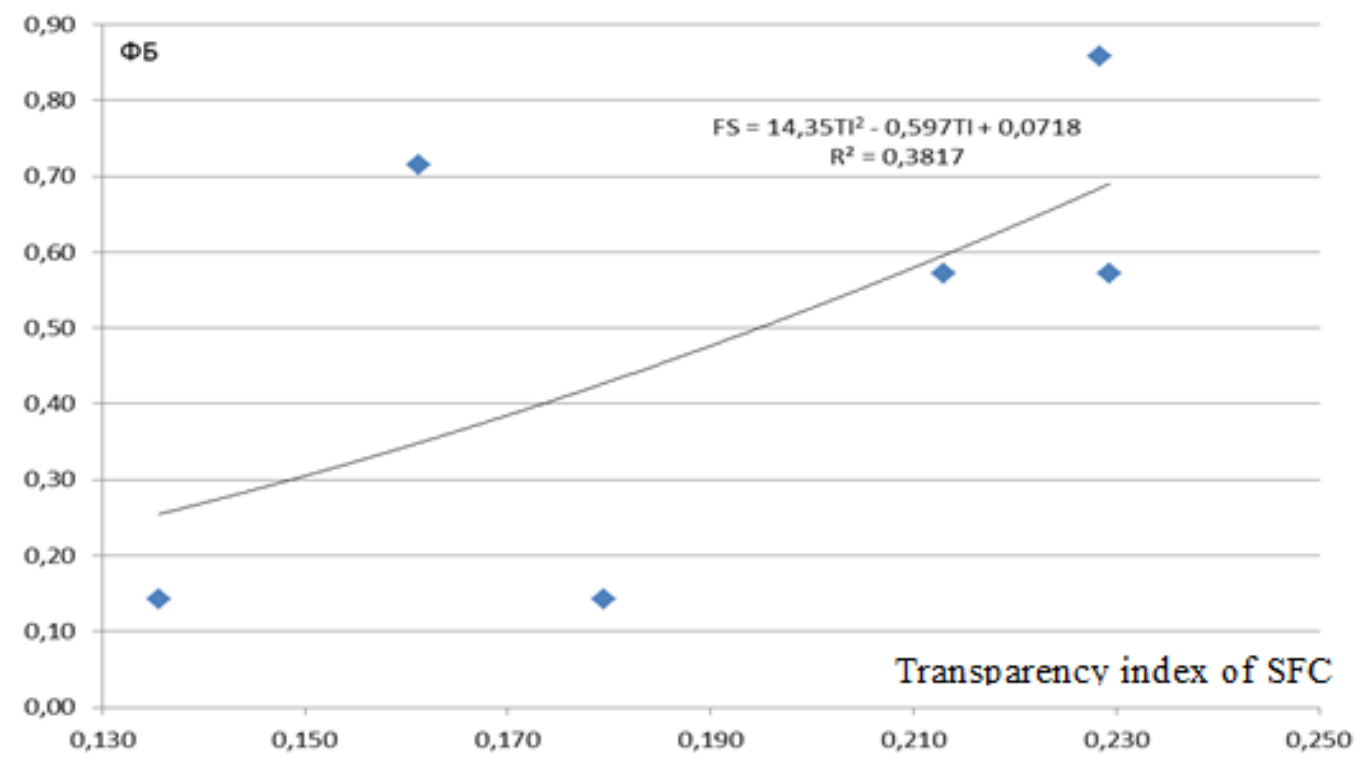

Figure 1. The main stages and results of the influence of transparency level of SFC (State Financial Inspection) on the level of FS (financial security) in Ukraine in 2010-2016

As can be seen from the above example, the significant density of the link between the transparency index of state financial control and the level of Ukrainian financial security creates the opportunity for constructing a functional dependence that is described by a second-degree polynomial with a coefficient of determination at a level of 0.38 .

\section{Conclusion}

Analyzing the openness of activities of the State Financial Inspection of Ukraine and the Accounting Chamber of Ukraine for the period of 2010-2016, which became the basis for calculating the transparency index of state financial control, authors calculate the value of normalized indicators of openness and transparency of state financial control as the average for the years studied. The use of regression analysis tools allowed formalizing its influence on the level of financial security in Ukraine. It was established that there is a direct link between the transparency index of state financial control and the level of financial security (the correlation coefficient was 0.62 ) in Ukraine, the functional relationship between which is described by a seconddegree polynomial with a coefficient of determination at a level of 0.38 . This shows that ensuring transparency of activities of state financial control authorities should be considered an effective direction of strengthening financial discipline, ultimately contributing to the level of financial security.

\section{References}

1. Allen, W. and Wood, G. (2006). Defining and achieving financial stability. Journal of Financial Stability, 2(2), 52-72.

2. Lambert, D. (1990). La defence de l'economie: la conjugaison des efforts de l'Etat, de l'enterprise et d'individu. Strategigue, 2, 83-98.

3. Nolan, R.L. (1973). Mananaging the Computer Resourse: A Stage Hypothesis. Communications of ACM, 16(7), 399-405.

4. What is ESI? [Electronic resource]. Retrieved from http://economicsecurityindex.org/?p=what is the esi.

5. Gerald H. Lander, Kathleen A. Auger (2008). The need for transparency in financial reporting: Implications of off-balance-sheet financing and inferences for the future. Journal of Accounting \& Organizational Change, 4(1), 27-46.

6. Deyoung, R., Flannery, M.J., Lang, W.W. and Sorescu, S.M. (2001). The information content of bank exam ratings and subordinated debt prices (statistical data included). Journal of Money, Credit \& Banking, 33(4), 900-925. 
7. Kaminsky, G.L. and Reinhart, C.M. (1999). The twin crises: the causes of banking and balance-ofpayments problems. American Economic Review, 89(3), 473-500.

8. Bradley, Caroline M. (June 25, 2012). Transparency and Financial Regulation in the European Union: Crisis and Complexity. Fordham International Law Journal, 35; University of Miami Legal Studies Research Paper No. 2012-15.

9. Directive 2001/34/EC, Official Journal of the European Communities, L 390, 31.12.2004, Brussels, pp. 38-57.

\section{Appendix}

Table 2. Normalized values of openness and transparency indicators of public financial control bodies and Integral Transparency Index for 2010-2016

\begin{tabular}{|c|c|c|c|c|c|c|c|}
\hline \multirow{2}{*}{ Indicators } & \multicolumn{7}{|c|}{ Years } \\
\hline & 2010 & 2011 & 2012 & 2013 & 2014 & 2015 & 2016 \\
\hline 1 & 2 & 3 & 4 & 5 & 6 & 7 & 8 \\
\hline $\begin{array}{l}\text { Number of press conferences and briefings of } \\
\text { specialists of the State Financial Inspection of } \\
\text { Ukraine, devoted to the prevention of corruption } \\
\text { in the use of public funds. }\end{array}$ & 0 & 0 & 1 & 1 & 1 & 0 & 1 \\
\hline $\begin{array}{l}\text { Number of information materials on the direc- } \\
\text { tions of work and results of activities of the State } \\
\text { Financial Inspection of Ukraine, prepared by } \\
\text { units responsible for the publication of infor- } \\
\text { mation in the media. }\end{array}$ & 0 & 0 & 0 & 1 & 1 & 1 & 1 \\
\hline $\begin{array}{l}\text { Number of answers of experts of the State Finan- } \\
\text { cial Inspection of Ukraine to official requests } \\
\text { from media representatives. }\end{array}$ & 0 & 0 & 0 & 0 & 1 & 0 & 1 \\
\hline $\begin{array}{l}\text { Number of responses of specialists from the State } \\
\text { Financial Inspection of Ukraine to information } \\
\text { requests from members of the public. }\end{array}$ & 1 & 1 & 1 & 0 & 0 & 0 & 0 \\
\hline $\begin{array}{l}\text { Number of informational materials on the direc- } \\
\text { tions of work and results of the Accounting } \\
\text { Chamber of Ukraine, published in the media. }\end{array}$ & 0 & 0 & 0 & 1 & 1 & 1 & 0 \\
\hline $\begin{array}{l}\text { The number of information messages on the work } \\
\text { of the State Financial Inspection of Ukraine on } \\
\text { the official website (in "News" section). }\end{array}$ & 0 & 0 & 0 & 0 & 1 & 1 & 1 \\
\hline $\begin{array}{l}\text { Publication of results of the State Financial In- } \\
\text { spection of Ukraine (in print, on television, } \\
\text { broadcasting, etc.). }\end{array}$ & 0 & 0 & 0 & 1 & 1 & 1 & 1 \\
\hline Integral assessment of transparency & 1 & 1 & 2 & 4 & 6 & 4 & 5 \\
\hline Transparency index & 0.14 & 0.14 & 0.29 & 0.57 & 0.86 & 0.57 & 0.71 \\
\hline
\end{tabular}

Source: own calculations. 